\title{
FILM EDIBEL ANTIBAKTERI BERBASIS ISOLAT PROTEIN KEDELAI DENGAN EKSTRAK KUNYIT DAN NANOPARTIKEL SENG OKSIDA
}

\author{
[Antibacterial Edible Films Made from Soy Protein Isolate with \\ Turmeric Extract and Zinc Oxide Nanoparticles]
}

\author{
Imawati Eka Putri ${ }^{1)}$, Nugraha Edhi Suyatma ${ }^{2) \star}$, dan Harsi Dewantari Kusumaningrum ${ }^{2)}$ \\ 1) Program Studi Ilmu Pangan, Sekolah Pascasarjana, Institut Pertanian Bogor, Bogor \\ 2) Departemen Ilmu dan Teknologi Pangan, Fakultas Teknologi Pertanian, Institut Pertanian Bogor, Bogor
}

Diterima 2 Februari 2018 / Disetujui 9 Mei 2018

\begin{abstract}
Soy protein isolate (SPI) is one of the base materials for edible film production in addition to polysaccharide and lipid, but it does not have antibacterial activities. Incorporation of antibacterial agents may increase the functional properties of the edible films. This research aimed to determine the effects of zinc oxide nanoparticles (ZnO-NPs) and turmeric extract addition into soy protein isolate-based films on the physical, mechanical and antibacterial characteristics of the films. The edible films were prepared by dissolving 5 grams of SPI into $100 \mathrm{~mL}$ of distilled water followed by the addition of ZnO-NPs (0, 1, and $2.5 \%$ of the SPI weight) and/or turmeric extracts (0 and $2.5 \%$ of the SPI weight). The results showed that addition of ZnO-NPs and turmeric extracts into the films significantly increased the thickness and values of tensile strength. Addition of turmeric extract decreased the percent of films elongation, while addition of ZnO-NPs had a significant effect in decreasing the water vapor transmission rate (WVTR) values. The combination of ZnO-NPs and turmeric extracst had a considerable effects in inhibiting E.coli growth in the range of $2.25 \mathrm{~mm}$ to $3.18 \mathrm{~mm}$. Meanwhile, addition of ZnO-NPs resulted in inhibition against E.coli in the range of $2.54 \mathrm{~mm}$ to $4.29 \mathrm{~mm}$. Furthermore, this research showed that addition of ZnO NPs and turmeric extracts could improve the physical and mechanical properties of SPI-based film. The best films was obtained by using ZnO NPs at 2.5\% which can potentially be used as an antibacterial packaging.
\end{abstract}

Keywords: films, nanoparticles, soy protein isolate, turmeric extracts, zinc oxide

\begin{abstract}
ABSTRAK
Isolat protein kedelai (IPK) merupakan salah satu bahan dasar pembentuk film selain polisakarida dan lipid, namun belum memiliki kemampuan antibakteri. Penambahan agen antibakteri dapat meningkatkan sifat fungsional edibel berbasis IPK. Penelitian ini bertujuan untuk mengetahui pengaruh penambahan NP-ZnO dan ekstrak kunyit terhadap karakteristik fisik, mekanis, dan aktivitas antibakteri edibel film berbasis isolat protein kedelai (IPK). Pembuatan film pada penelitian ini dilakukan dengan melarutkan 5 gram IPK ke dalam $100 \mathrm{~mL}$ akuades dan diberi penambahan NP-ZnO (0; 1; dan 2,5\% b/b IPK) serta penambahan ekstrak kunyit (0 dan 2,5\% b/b IPK). Hasil penelitian menunjukkan bahwa penambahan NP$\mathrm{ZnO}$ dan ekstrak kunyit dapat meningkatkan ketebalan dan nilai kuat tarik film secara nyata. Sedang-kan penggunaan ekstrak kunyit mampu menurunkan nilai persen elongasi secara signifikan. Penambahan NP$\mathrm{ZnO}$ berpengaruh nyata dalam menurunkan nilai water vapor transmission rate (WVTR). Kombinasi NP$\mathrm{ZnO}$ dan ekstrak kunyit dapat menghambat pertumbuhan E.coli pada kisaran 2,55 mm sampai 3,18 mm. Sementara penambahan NP-ZnO dapat menghambat pertumbuhan E.coli pada kisaran 2,54 mm sampai 4,29 mm. Hasil penelitian ini menunjukkan bahwa penambahan NP-ZnO dan ekstrak kunyit mam-pu memberikan pengaruh terhadap karakteristik fisik dan mekanis film berbasis IPK. Perlakuan terbaik didapat dengan konsentrasi NP-ZnO sebesar 2,5\% yang berpotensi digunakan sebagai kemasan antibakteri.
\end{abstract}

Kata Kunci: ekstrak kunyit, film, isolat protein kedelai, nanopartikel, seng oksida

\section{PENDAHULUAN}

Film edibel merupakan salah satu alternatif pengembangan kemasan yang dapat langsung dikon-

\footnotetext{
*Penulis Korespondensi:

E-mail: nugrahaedhi@yahoo.com
}

sumsi bersama produk pangan yang dikemasnya. Selain itu edibel film juga mudah didegradasi. Film edibel didefinisikan sebagai lembaran tipis yang umum diaplikasikan pada komponen makanan yang dapat terbuat dari polisakarida (selulosa, pati, kitosan), protein (kolagen, kasein, whey protein, protein kedelai, gluten, zein), lipid, maupun 
kombinasi bahan-bahan tersebut (Krochta dan Johnston, 2002). Pada umumnya polisakarida sering digunakan sebagai pengemas karena bersifat mudah larut dalam air sehingga mudah dalam pembuatannya dan memiliki kemampuan sebagai penghalang terhadap oksigen, karbondioksida, lemak dan memiliki sifat mekanis yang baik. Namun film yang terbuat dari polisakarida tidak dapat menghalangi migrasi uap air dengan baik. Penggunaan protein sebagai bahan dasar edibel film menghasilkan film yang lebih baik dibandingkan dengan polisakarida karena memiliki sifat yang lebih hidrofob sehingga mampu menahan uap air dan efisien sebagai penghalang oksigen dan lemak (Shon dan Choi, 2011).

Isolat protein kedelai (IPK) merupakan salah satu bahan dasar yang umum digunakan dalam pembuatan edibel film berbasis protein. Kelebihan IPK sebagai bahan dasar edibel film diantaranya memiliki kemampuan menahan uap air dan gas (Wan et al., 2005), mampu menurunkan permeabilitas oksigen, mampu meningkatkan sifat fungsional dan sifat mekanis film (Nandane dan Jain, 2014). Akan tetapi edibel film berbasis IPK tidak memiliki kemampuan antibakteri sehingga kerusakan produk oleh bakteri masih dapat terjadi. Oleh karena itu alternatif yang dapat dilakukan adalah dengan menambahkan bahan pengisi (filler) dengan menambahkan zat antibakteri antara lain nanopartikel seng oksida (NP-ZnO) dan ekstrak kunyit.

Singh dan Nanda (2013) melaporkan bahwa $\mathrm{NP}-\mathrm{ZnO}$ dengan konsentrasi $25 \mu \mathrm{g} / \mathrm{mL}$ mampu menghambat pertumbuhan bakteri Escherichia coli, Staphylococcus aureus, dan Bacillus subtilis. NP$\mathrm{ZnO}$ yang ditambahkan ke dalam film berbasis tapioka sebanyak 1 dan $2 \%$ mampu memberikan pengaruh yang signifikan terhadap ketebalan, nilai kuat tarik, elongasi, dan laju transmisi uap air film serta dapat menekan laju pertumbuhan mikroba pada aplikasinya terhadap mangga terolah minimal selama penyimpanan (Wardana, 2016). Selain itu penggunaan kunyit sebagai senyawa antibakteri telah banyak diketahui. Amaliya dan Putri (2014) menyatakan bahwa ekstrak kunyit memiliki kandungan beberapa senyawa aktif seperti alkaloid, fenol, kurkumin, minyak atsiri, dan flavonoid yang mampu menghambat pertumbuhan mikroorganisme. Penambahan ekstrak kunyit kedalam film berbasis tapioka mampu meningkatkan nilai elongasi, menurunkan nilai kuat tarik, berpengaruh terhadap ketebalan film dan menghasilkan diameter zona hambat yang lebih besar dibandingkan kontrol (Muin et al., 2017).

Penelitian mengenai pemanfaatan NP-ZnO sebagai bahan pengisi dalam pembuatan film telah banyak dilakukan (Arfat et al., 2015; Panea et al., 2014; Silva et al., 2015), begitupun dengan penambahan ekstrak kunyit sebagai bahan pengisi dalam edibel film (Kavas dan Kavas, 2017; Utami et al.,
2013; Kalaycioglu et al., 2017) namun studi mengenai interaksi keduanya belum banyak diketahui. Oleh karena itu penelitian ini bertujuan untuk mengetahui pengaruh NP-ZnO dan ekstrak kunyit pada edibel film berbasis IPK ditinjau dari karakteristik fisik, mekanis, dan aktivitas antibakteri.

\section{BAHAN DAN METODE}

\section{Bahan}

Bahan utama yang digunakan pada penelitian ini adalah isolat protein kedelai (IPK) komersil (Marksoy 90) yang diperoleh dari Guyun Economic Development Zone Shenxian China, nanopartikel $\mathrm{ZnO}$ dengan ukuran partikel rata-rata $20 \mathrm{~nm}$ (Wako, Jepang), rimpang kunyit varietas Turina 2 dengan umur panen 10 bulan yang didapat dari Balai Penelitian Tanaman Rempah dan Obat (BALITRO) Bogor.

\section{Pembuatan ekstrak kunyit}

Pembuatan ekstrak kunyit dimulai dengan pembuatan simplisia kunyit. Kunyit dicuci dan ditiriskan, lalu diiris tipis dengan ketebalan $\pm 3 \mathrm{~mm}$. Selanjutnya irisan kunyit dikeringkan dengan oven pada suhu $40^{\circ} \mathrm{C}$ selama $25 \mathrm{jam}$. Setelah kering, kunyit dihaluskan dengan blender (Cosmos CB-721 G, Indonesia) selama \pm 30 detik pada kecepatan maksimum kemudian disaring dengan ayakan 60 mesh untuk mendapatkan simplisia kunyit. Simplisia kunyit yang sudah didapat kemudian dicampurkan dengan etil asetat (Brataco, Indonesia) sebagai pelarut dengan rasio bahan:pelarut adalah 1:4, proses ekstraksi kunyit ini dilakukan dengan menggunakan metode maserasi (Danggi 2008). Kunyit yang bercampur dengan pelarut di shaker (GFL, D3006, Jerman) selama 24 jam pada kecepatan $100 \mathrm{rpm}$. Selanjutnya dilakukan penyaringan dengan menggunakan vacuum filter untuk memisahkan filtrat. Filtrat yang masih bercampur dengan pelarut kemudian diuapkan dengan menggunakan rotary evaporator (BUCHI, Swiss) pada suhu $50^{\circ} \mathrm{C}$ dengan tekanan 200 mbar sehingga didapatkan ekstrak kunyit. Ekstrak kunyit yang didapat kemudian dilakukan pengujian daya hambat dengan menggunakan bakteri uji E.coli ATCC 25922 untuk mengetahui diameter zona hambat dari ekstrak kunyit yang terbentuk. Pengukuran diameter zona hambat dilakukan dengan menggunakan jangka sorong.

\section{Pembuatan film edibel}

NP-ZnO $(0 ; 1$; dan $2,5 \%$ b/b IPK) dilarutkan ke dalam $100 \mathrm{~mL}$ akuades dengan menggunakan ultraturax (IKA, T25, Jerman) 10000 rpm hingga homogen ( \pm 10 menit). Selanjutnya sebanyak 5 gram IPK ditambahkan ke dalam larutan sedikit demi sedikit dan dipanaskan di atas hotplate dengan suhu $40^{\circ} \mathrm{C}$. 
Kemudian ditambahkan gliserol (Ecogreen Oleochemical, Indonesia) 20\% (b/b IPK) untuk meningkatkan elastisitas film sambil terus diaduk dengan magnetic stirrer. Larutan edibel ini kemudian dipanaskan hingga suhu $70^{\circ} \mathrm{C}$ dan ditahan selama 20 menit. Setelah 20 menit dan suhu menurun hingga $\pm 40^{\circ} \mathrm{C}$ ditambahkan ekstrak kunyit (0; dan 2,5\% b/b IPK) lalu diaduk hingga rata kemudian dituang sebanyak $10 \mathrm{~mL}$ ke dalam cawan petri plastik berdiameter $80 \mathrm{~mm}$ dan dikeringkan pada suhu ruang selama 24 jam. Film yang sudah terbentuk kemudian diangkat dan dimasukan ke dalam desikator dengan $\mathrm{RH} 56 \%$ dan suhu $27^{\circ} \mathrm{C}$ sebelum dilakukan analisis. Formula edibel film dapat dilihat pada Tabel 1.

Tabel 1. Formula edibel film berbasis IPK dengan ekstrak kunyit dan NP-ZnO

\begin{tabular}{ccc}
\hline $\begin{array}{c}\text { Konsentrasi } \\
\text { NP-ZnO }(\%)\end{array}$ & $\begin{array}{c}\text { Konsentrasi } \\
\text { Ekstrak Kunyit } \\
(\%)\end{array}$ & $\begin{array}{c}\text { Isolat Protein } \\
\text { Kedelai/Soy Isolate } \\
\text { Protein (g) }\end{array}$ \\
\hline 0 & 0 & 5 \\
1 & 0 & 5 \\
2,5 & 0 & 5 \\
0 & 2,5 & 5 \\
1 & 2,5 & 5 \\
2,5 & 2,5 & 5 \\
\hline
\end{tabular}

\section{Analisis sifat fisik film}

Parameter sifat fisik yang dilakukan pada penelitian ini meliputi pengukuran ketebalan film dan pengukuran laju transmisi uap air/water vapor transmission rate (WVTR). Tebal film pada penelitian ini di ukur menggunakan mikrometer sekrup dengan akurasi $0,01 \mathrm{~mm}$ dan dilakukan pada 10 titik berbeda sebanyak 2 kali ulangan, yang kemudian hasilnya dirata-ratakan. Pengukuran WVTR diukur berdasarkan metode ASTM D 1249-90 (1993) dengan sedikit modifikasi. Bahan penyerap uap air $\left(\mathrm{CaCl}_{2}\right)$ (Merck, Jerman) dengan $\mathrm{RH} 2 \%$ diletakkan di dalam wadah, kemudian sampel edibel film dipotong dengan diameter $30 \mathrm{~mm}$ dan diletakan di atas wadah yang sudah berisi bahan penyerap uap air $\left(\mathrm{CaCl}_{2}\right)$ (Merck, Jerman) kemudian ditutup dengan parafilm sehingga tidak ada udara masuk. Wadah berisi $\mathrm{CaCl}_{2}$ (Merck, Jerman) dan edibel film kemudian di simpan dalam desikator yang berisi $\mathrm{KCl}$ (Merck, Jerman) jenuh dengan $\mathrm{RH} 85 \%$ dan suhu $27^{\circ} \mathrm{C}$. Selanjutnya, wadah ditimbang secara berkala. Laju transmisi uap air (WVTR) $\left(\mathrm{g} / \mathrm{m}^{2} \mathrm{jam}\right)$ dihitung dari kemiringan garis (slope) yang dihasilkan dari analisis regresi bobot sebagai fungsi waktu.

\section{Analisis sifat mekanis film}

Sifat mekanis dari edibel film berbasis IPK meliputi kuat tarik dan persentase pemanjangan/ elongasi film yang diukur menggunakan Microcomputer Controlled Universal Testing Machine (Instron, USA) dengan kecepatan $20 \mathrm{~mm} /$ menit dan beban $100 \mathrm{kgf}$. Analisis kuat tarik ini dilakukan berdasarkan metode standar ASTM D 882-02 (2002). Nilai kuat tarik dari film diperoleh berdasarkan beban maksimum pada saat film putus sedangkan nilai elongasi diukur dari selisih perpanjangan film awal dan saat film putus. Secara sistematis hubungan tersebut dapat dirumuskan sebagai berikut:

$$
\text { Kuat Tarik }=\frac{F}{A}
$$

dimana $\mathrm{F}$ merupakan gaya tarik $(\mathrm{N})$ dan $\mathrm{A}$ adalah luas penampang bidang gaya $\left(\mathrm{mm}^{2}\right)$, sedangkan nilai a adalah panjang film awal $(\mathrm{m})$ dan $\mathrm{b}$ adalah panjang film akhir $(\mathrm{m})$.

$$
\% \text { Elongasi }=\frac{\mathrm{b}-\mathrm{a}}{\mathrm{a}} \times 100 \%
$$

\section{Analisis aktivitas antibakteri}

Analisis antibakteri pada penelitian ini menggunakan metode difusi sumur dengan bakteri uji adalah E.coli ATCC 25922. Bakteri yang sudah diinokulasikan selama 24 jam kemudian di ambil sebanyak $25 \mu \mathrm{L}$ dan dimasukkan ke dalam $25 \mathrm{~mL}$ media Mueller Hinton Agar (MHA). Campuran ini kemudian dihomogenkan dan dibiarkan hingga memadat. Media yang telah memadat kemudian dibuat lubang sumur sebesar $\pm 6 \mathrm{~mm}$. Selanjutnya larutan sampel edibel film sebanyak $50 \mu \mathrm{L}$ dimasukan kedalam lubang dan diinkubasi selama 24 jam pada suhu $37^{\circ} \mathrm{C}$ lalu dilakukan pengamatan zona bening yang terbentuk dan dilakukan pengukuran lebar zona bening menggunakan jangka sorong.

\section{Rancangan percobaan dan analisis data}

Percobaan dilakukan menggunakan rancangan acak lengkap faktorial (2 faktor) dengan kombinasi 3 taraf konsentrasi NP-ZnO dan 2 taraf konsentrasi ekstrak kunyit dan dilakukan sebanyak dua kali ulangan. Analisis data dilakukan dengan menggunakan piranti lunak SPSS 20.0 dengan analisis sidik ragam (ANOVA) pada taraf signifikansi $5 \%$ dan dilanjutkan dengan uji Duncan Multiple Range Test (DMRT).

\section{HASIL DAN PEMBAHASAN}

\section{Ekstrak kunyit}

Rendemen ekstrak kunyit yang diperoleh pada penelitian ini adalah sebesar $21,8 \%$. Dewi et al. (2016) menyatakan kunyit varietas Turina 1 dengan umur panen 10 bulan mampu menghasilkan rendemen sebesar $18,24 \%$. Umur panen kunyit berpengaruh terhadap rendemen yang dihasilkan, semakin lama umur panen maka semakin banyak jumlah zat aktif yang terbentuk dan rendemen yang dihasilkan akan semakin tinggi (Dewi et al., 2016). Diameter 
zona hambat yang terbentuk oleh ekstrak kunyit adalah sebesar 19,83 mm (Gambar 1) yang termasuk dalam kategori kuat karena memiliki diameter zona hambat lebih dari $10 \mathrm{~mm}$ (Rita, 2010). Namun hasil yang berbeda didapatkan oleh Adila et al. (2013) dan Rahmawati et al. (2014) yang menunjukkan bahwa ekstrak kunyit menghasilkan diameter zona hambat terhadap bakteri $E$. coli masing-masing sebesar 10,16 mm dan 5,64 mm. Perbedaan rendemen ekstrak kunyit dan diameter zona hambat yang terbentuk diduga dipengaruhi oleh jumlah dan jenis pelarut, varietas kunyit dan metode yang digunakan. Adanya senyawa kurkumin pada kunyit mampu menghambat pertumbuhan bakteri karena adanya senyawa fenolik yang mampu mengganggu permeabilitas membran sel dan menyebabkan kematian bakteri (Dermawaty, 2015).

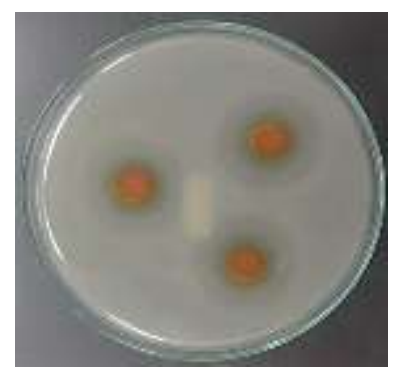

Gambar 1. Diameter zona hambat ekstrak kunyit

\section{Karakteristik fisik film edibel}

Karakteristik edibel film dapat dilihat pada Tabel 2. Ketebalan film yang dihasilkan berkisar antara 0,06-0,12 mm. Penambahan NP-ZnO dan ekstrak kunyit dengan konsentrasi 2,5\% berbeda nyata dengan perlakuan konsentrasi $0 \%$. Namun interaksi antara keduanya menunjukkan tidak adanya perbedaan yang nyata. Peningkatan konsentrasi NP-ZnO akan menyebabkan total padatan pada film akan semakin banyak dan ketebalan film akan semakin meningkat. Wardana (2016) melaporkan penambahan NP-ZnO dapat meningkatkan ketebalan film berbasis tapioka. Ekstrak kunyit juga dapat meningkatkan ketebalan film. Diduga adanya kandungan pati pada ekstrak kunyit mampu meningkatkan jumlah padatan pada film sehingga ketebalan film pun akan semakin meningkat. Penelitian Amaliya dan Putri (2014) menunjukkan bahwa penambahan ekstrak kunyit putih ke dalam film berbasis pati jagung dapat meningkatkan ketebalan film dari 0,05 menjadi $0,250 \mathrm{~mm}$. Hal tersebut menunjukkan bahwa semakin banyak total padatan yang ditambahkan ke dalam film maka ketebalan film akan semakin meningkat dan akan memengaruhi sifat mekanis serta permeabilitas film yang dihasilkan.

Pengukuran laju transmisi uap air/water vapor transmission rate (WVTR) bertujuan untuk mengetahui kecepatan uap air dalam menembus film pada kondisi kelembaban dan luas serta waktu tertentu. Penambahan NP-ZnO pada konsentrasi 2,5\% mampu menurunkan nilai WVTR secara nyata (Tabel 2). Interaksi antara NP-ZnO dan ekstrak kunyit menunjukkan adanya pengaruh yang nyata. NP-ZnO mampu menjadi penghalang uap air dalam menembus film. Ukuran partikel dalam skala nanometer menyebabkan perpindahan air menjadi sulit karena adanya mekanisme jalur berliku yang semakin panjang. Hal ini sesuai dengan penelitian yang dilakukan oleh Nafchi et al. (2012) dan Meindrawan et al. (2016) dimana penambahan NP-ZnO dapat menurunkan permeabilitas uap air secara signifikan ke dalam polimer film yang masing-masing berbasis pati sagu dan karagenan, karena NP-ZnO mampu mengisi struktur makromolekul polimer dan mengurangi permeabilitas uap air. Yu et al. (2009) juga menyatakan bahwa NP-ZnO mempunyai resistensi yang baik terhadap air, sehingga penambahan NP-ZnO dapat memberikan penghalang bagi molekul air untuk lewat dan permeabilitas uap air akan menurun.

Tabel 2. Nilai WVTR dan tebal film berbasis IPK dengan ekstrak kunyit dan NP-ZnO

\begin{tabular}{ccc}
\hline Konsentrasi ZnO (\%) & Konsentrasi Ekstrak Kunyit $(\%)$ \\
\hline Ketebalan Film $(\mathrm{mm})$ & 0 & 2,5 \\
\hline 0 & $0,06 \pm 0,00^{\mathrm{Aa}}$ & $0,09 \pm 0,00^{\text {Aa }}$ \\
1 & $0,09 \pm 0,00^{\text {Aab }}$ & $0,09 \pm 0,00^{\text {Aab }}$ \\
2,5 & $0,09 \pm 0,00^{\text {Ab }}$ & $0.12 \pm 0.04^{\text {Ab }}$ \\
\hline WVTR $\left(\mathrm{g} / \mathrm{m}^{2}\right.$ jam $)$ & $21,03 \pm 0,08^{\text {Ab }}$ & $18,64 \pm 0,41^{\text {Ab }}$ \\
0 & $17,74 \pm 0,23^{\text {Aa }}$ & $16,46 \pm 2,38^{\text {Aa }}$ \\
1 & $16,52 \pm 0,15^{\text {Aa }}$ & $19,63 \pm 0,21^{\text {Aa }}$ \\
2,5 &
\end{tabular}

Keterangan: *Perbedaan huruf kapital pada baris yang sama menunjukkan pengaruh nyata pada konsentrasi kunyit pada taraf nyata $\alpha=5 \%$; ${ }^{* *}$ Perbedaan huruf kecil pada baris yang sama menunjukkan pengaruh nyata pada konsentrasi NP-ZnO pada taraf nyata $\alpha=5 \%$

Penambahan ekstrak kunyit juga mampu menurunkan nilai WVTR namun menunjukkan nilai yang fluktuatif (Tabel 2). Menurunnya nilai WVTR diduga karena adanya senyawa hidrofobik (Bourbon, 2011) seperti minyak atsiri yang terkandung pada ekstrak kunyit yang mampu membatasi interaksi antara polimer film dengan air yang berikatan hidrogen sehingga mengakibatkan terjadinya penurunan kadar air dan permeabilitas uap air pun menurun (Ojagh et al., 2010). Edibel film yang mempunyai nilai WVTR rendah cocok digunakan untuk mengemas produk dengan kelembaban tinggi karena mampu menghambat jumlah uap air yang dikeluarkan dari produk ke lingkungan dan mampu melindungi produk dari uap air yang masuk dari lingkungan, sehingga dapat mengurangi kelembapan dan kontaminasi yang dapat mengakibatkan tumbuhnya mikroorganisme dan menurunkan kualitas produk.

Nilai WVTR yang terlihat fluktuatif karena adanya penambahan ekstrak kunyit (Tabel 2) diduga 
akibat tidak meratanya ekstrak kunyit yang ditambahkan ke dalam film sehingga berpengaruh terhadap hasil yang didapat. Hasil yang sama dinyatakan oleh Kalaycioglu et al. (2017) dimana penambahan ekstrak kunyit kedalam film berbasis kitosan tidak berpengaruh signifikan dalam menurunkan nilai WVTR.

\section{Karakteristik mekanis film edibel}

Nilai kuat tarik semakin meningkat dan nilai elongasi semakin menurun seiring dengan adanya penambahan NP-ZnO dan ekstrak kunyit (Gambar 2a). Hasil analisis sidik ragam menunjukkan tidak adanya pengaruh yang nyata antara NP-ZnO dan ekstrak kunyit. Adanya kandungan pati pada ekstrak kunyit dan adanya padatan yang berasal dari NP$\mathrm{ZnO}$ membuat interaksi intermolekul antar rantai polimer film menjadi lebih tebal sehingga film sulit putus dan nilai kuat tarik semakin tinggi. Baek dan Song (2017) melaporkan bahwa penambahan NP$\mathrm{ZnO}$ pada film berbasis Gracilaria vermiculophylla extract (GVE) dapat meningkatkan nilai kuat tarik dari $38,29 \mathrm{MPa}$ menjadi $41,39 \mathrm{MPa}$ dan menurunkan nilai elongasi dari $18,97 \%$ menjadi $16,57 \%$. Penambahan nano-partikel juga dapat menyebabkan kontak air dan matriks terganggu sehingga elongasi menurun (Torabi dan Nafchi, 2013). Hal ini membuktikan bahwa karakteristik mekanis film sangat dipengaruhi oleh banyaknya bahan pengisi yang digunakan. Penambahan NP-ZnO menyebabkan terjadinya perubahan struktur morfologi dari polimer film. Diduga hal inilah yang mengakibatkan terjadinya perbedaan nilai antara kuat tarik dan nilai elongasi (Kanmani dan Rhim, 2014).

Gambar 2b memperlihatkan bahwa semakin tinggi konsentrasi ekstrak kunyit yang ditambahkan ke dalam film maka nilai elongasi semakin menurun. Pada penelitiannya Muin et al. (2017) juga menunjukkan hal yang sama, dimana penambahan ekstrak kunyit putih sebanyak $1,2 \mathrm{~mL}$ kedalam film berbasis tapioka menghasilkan nilai elongasi yang lebih besar dibandingkan dengan kontrol. Liu et al. (2016) juga melaporkan bahwa adanya penambahan ekstrak kunyit sebanyak $1 \%$ ke dalam polimer film berbasis kitosan mampu menurunkan nilai elongasi dari $79,13 \%$ menjadi $39,41 \%$. Semakin banyak konsentrasi bahan pengisi ke dalam film membuat jumlah padatan semakin banyak dan film semakin tebal, namun ruang intermolekular polimer matriks tidak merenggang sempurna sehingga film yang dihasilkan tidak fleksibel.

\section{Aktivitas antibakteri}

Gambar 3 menunjukkan aktivitas penghambatan pertumbuhan bakteri E.coli pada edibel film berdasarkan diameter zona hambat yang terbentuk. Terlihat pada Gambar 3, penambahan NP-ZnO sebesar 2,5\% mampu menghasilkan diameter zona hambat sebesar 4,29 $\mathrm{mm}$. Sementara kombinasinya dengan ekstrak kunyit 2,5\% menghasilkan diameter zona hambat sebesar $3,18 \mathrm{~mm}$. Penambahan NP$\mathrm{ZnO}$ ke dalam larutan film dapat membentuk reactive oxygen species (ROS) yang mampu menembus dinding sel bakteri (Yousef et al., 2012). Aktivitas antibakteri NP-ZnO terjadi karena adanya interaksi antara hidrogen peroksida dengan protein membran, dimana hidrogen peroksida mampu memasuki membran sel bakteri dan menyebabkan kebocoran sel (Singh dan Nanda, 2013). Selain itu, ZnO dalam ukuran nanopartikel memberikan efek penghambatan yang jauh lebih efektif dan mampu berpenetrasi ke dalam dinding sel bakteri lebih mudah (Dhivya et al., 2015).
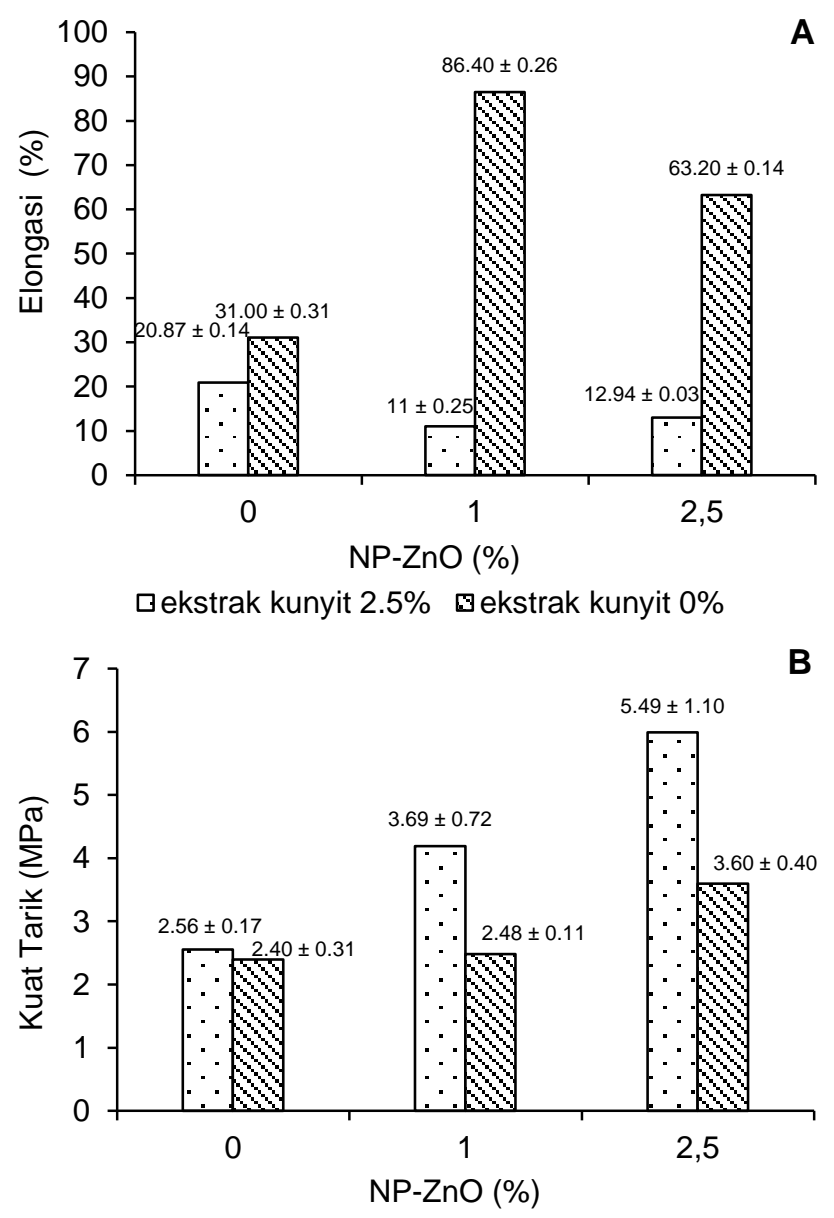

口ekstrak kunyit 2.5\% घekstrak kunyit 0\%

Keterangan: $A=$ nilai elongasi $(\% E B)$ edibel film; $B=$ nilai kuat tarik edibel film

\section{Gambar 2. Karakteristik mekanis edibel film}

Pasaraeng et al. (2013) mengungkapkan bahwa kurukumin yang terkandung dalam ekstrak kunyit memiliki mekanisme penghambatan bakteri dengan merusak membran sitoplasma dan mendenaturasi protein sel sehingga menganggu permeabilitas membran dan menyebabkan kebocoran. Hal ini me- 
ngakibatkan keluarnya nutrien sehingga pertumbuhan sel terhambat dan mati. Putri (2016) menambahkan bahwa kurkumin bekerja secara efektif dalam menghambat pertumbuhan bakteri dengan memecah protein menjadi molekul-molekul yang lebih sederhana (seperti asam amino) sehingga metabolisme mikroba terhambat dan sel pun mati.

Penambahan ekstrak kunyit dengan konsentrasi $2 \%$ kedalam film berbasis kitosan mampu menghambat pertumbuhan B.cereus dan E.coli (Danggi, 2008). Hasil uji statistik menunjukkan tidak adanya pengaruh yang signifikan antara penambahan NP-ZnO dan ekstrak kunyit $(P>0,05)$. Diduga adanya ketidak sinergisan antara NP-ZnO dan ekstrak kunyit dapat menurunkan aktivitas antibakteri. Hasil penelitian ini menunjukkan bahwa penambahan NP-ZnO sebesar 2,5\% menunjukkan hasil terbaik pada aktivitas antibakteri dengan diameter daya hambat terbesar, yaitu $4,29 \mathrm{~mm}$. Hal ini membuktikan bahwa NP-ZnO mampu menghambat pertumbuhan E.coli secara signifikan dibandingkan dengan kombinasinya dengan kunyit.

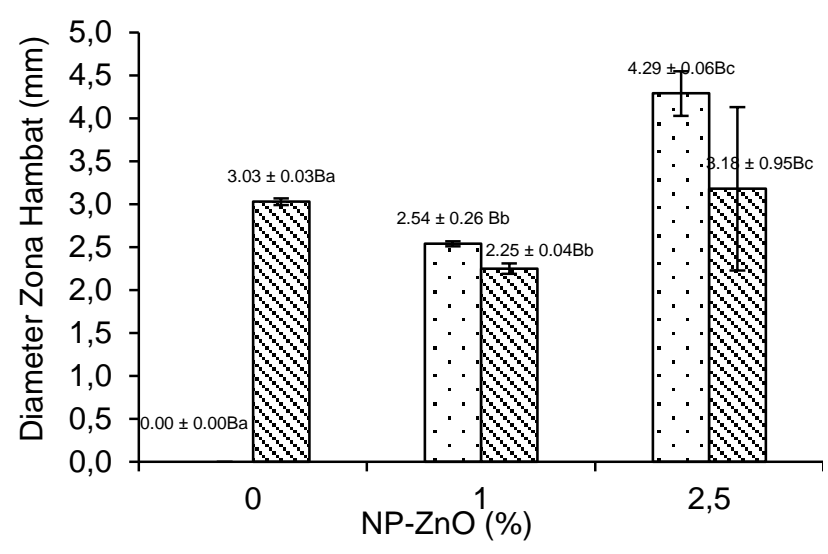

口ekstrak kunyit 0\% घekstrak kunyit 2.5\%

Gambar 3. Grafik diameter zona hambat dari larutan edibel terhadap bakteri E.coli

\section{KESIMPULAN}

Penambahan NP-ZnO dan ekstrak kunyit berpengaruh terhadap karakteristik fisik, mekanis dan aktivitas antibakteri film berbasis IPK. Berdasarkan hasil yang diperoleh penambahan NP-ZnO sebesar 2,5\% menunjukkan hasil terbaik pada aktivitas antibakteri dibandingkan kombinasinya dengan ekstrak kunyit, menghasilkan nilai WVTR sebesar 16,52 $\mathrm{g} / \mathrm{m}^{2}$ jam, nilai kuat tarik sebesar 3,6 MPa, dan nilai elongasi sebesar $63,2 \%$. Penelitian lebih lanjut perlu dilakukan untuk mengetahui potensi edibel film yang diaplikasikan pada produk makanan untuk mempertahankan kualitasnya.

\section{DAFTAR PUSTAKA}

[ASTM] American Society for Testing and Material. 1993. Standard Test Method For Water Vapor Transmission Rate Through Plastic Film And Sheeting Using A Modulated Infrared Sensor. Annual Book of American Standard Testing Methods D1249-90. Philadelphia.

[ASTM] American Society for Testing and Material. 2002. Standard Test Method For Tensile Properties Of Plastics. Standard Designation: D 882-02. Philadelphia.

Adila R, Nurmiati, Agustien A. 2013. Uji Antimikroba curcuma spp. terhadap pertumbuhan Candida albicans, Staphylococcus aureus, dan Escherichia coli. J Biologi Universitas Andalas 2: 1-7.

Amaliya RR, Putri WDR. 2014. Karakterisasi edibel film dari pati jagung dengan penambahan filtrat kunyit putih sebagai antibakteri. J Pangan Agroindustri 2: 45-53.

Arfat YA, Benjakul S, Prodpran T, Sumpavapol P, Songtipya P. 2015. Physico-mechanical characterization and antimicrobial properties of fish protein isolate/fish skin gelatin-zinc oxide $(\mathrm{ZnO})$ nanocomposite films. Food Bioprocess Tech 9: 101-112. DOI: 10.1007/s11947-015-1602-0

Baek SK, Song KB. 2017. Development of Gracillaria vermiculophylla extract films containing zinc oxide nanoparticles and their application in smoked salmon packaging. LWT-J Food Sci Technol 89: 269-275. DOI: 10.1016/j.Iwt.2017. 10.064 .

Bourbon Al, Pinheiro AC, Cerqueira MA, Rocha CMR, Avides MC, Quintas MAC, Vicente AA. 2011. Physico-chemical characterization of chitosan-based film incorporating bioactive compounds of different molecular weight. J Food Eng 106: 111-118. DOI: 10.1016/j.jfoodeng.201 1.03.024.

Danggi E. 2008. Aplikasi Kitosan Dengan Penambahan Esensial Oil Kunyit sebagai Pengawet dan Edibel Coating Produk Tahu. [Tesis]. Bogor: Fakultas Teknologi Pertanian, Institut Pertanian Bogor.

Dermawaty DE. 2015. Potential extract curcuma (Curcuma xanthorrizal, Roxb) as antibacterials. J Majority 4: 5-11.

Dewi PJN, Hartiati A, Mulyani S. 2016. pengaruh umur panen dan tingkat maserasi terhadap kandungan kurkumin dan aktivitas antioksidan ekstrak kunyit (Curcuma domestica Val.). J Rekayasa Manajemen Agroindustri 4: 101-111. 
Dhivya RJ, Ranjani J, Rajendhran M, Rajasekaran J, Annaraj. 2015. $\mathrm{Ph}$ responsive curcumin/ZnO nanocomposite for drug delivery. Adv Mater Lett 6: 505-512. DOI: 10.5185/amlett.2015.57 66.

Kalaycioglu Z, Torlak E, Evingur GA, Ozen I, Erim B. 2017. Antimicrobial and physical properties of chitosan films incorporated with turmeric extract. Int J Biol Macromol 101: 882-888. DOI: 10. 1016/j.ijbiomac.2017.03.174.

Kanmani P, Rhim JW. 2014. Properties and characterization of bionanocomposite films prepared with various biopolymers and $\mathrm{ZnO}$ nanoparticles. Carbohyd Polym 106: 190-199. DOI: 10. 1016/j.carbpol.2014.02.007.

Kavas N, Kavas G. 2017. Use of turmeric (Curcuma longa L.) essential oil added to an egg white protein powder-based film in the storage of cokelek cheese. J Food Chem Nanotechnol 3: 105-110. DOI: 10.17756/jfcn.2017-045.

Krochta JM, Johnston MC. 1997. Edible and Biodegradable Polymer Films: Challenges and Oppurtunities. J Food Technol 51: 61-74.

Liu Y, Cai Y, Jiang X, Wu J, Le X. 2016. Molecular interactions, characterization and antimicrobial activity of curcumin-chitosan blend films. Food Hydrocolloids 52: 564-572. DOI: 10.1016/j.food hyd.2015.08.005.

Meindrawan B, Suyatma NE, Muchtadi TR, Iriani ES. 2016. Preparation and characterization of bionanocomposite films made from carrageenan, beeswax and $\mathrm{ZnO}$ nanoparticles. Mater Sci Forum Trans Tech Publication, Switzerland 872: 157-161. DOI: 10.4028/www.scientific.net/ MSF.872.157.

Muin R, Anggraini D, Malau F. 2017. Karakteristik fisik dan antimikroba edible film dari tepung tapioka dengan penambahan gliserol dan kunyit putih. J Teknik Kimia 3: 191-198.

Nafchi AM, Alias AK, Mahmud S, Robal M. 2012. Antimicrobial rheological and physicochemical properties of sago starch film filled with nanorods rich zinc oxide. J Food Eng 113: 511-519. DOI: 10.1016/j.jfoodeng.2012.07.017.

Nandane AS, Jain R. 2014. Study of mechanical properties of soy protein based edible film as affected by its composition and process parameters by using RSM. J Food Sci Technol 52: 3645-3650. DOI: 10.1007/s13197-014-1417-4.
Ojagh SM, Rezaei M, Razavi SH, Hosseini SMH. 2010. Development and evaluation of a novel biodegradable film made from chitosan and cinnamon essential oil with low affinity toward water. Food Chem 122: 161-166. DOI: 10.1016/ j.foodchem.2010.02.033.

Panea B. Ripoll G, Gonzalez J, Cuello AF, Alberti P. 2014. Effect of nanocomposite packaging containing different proportions of $\mathrm{ZnO}$ and $\mathrm{Ag}$ on chicken breast meat quality. J Food Eng 123: 104-112. DOI: 10.1016/j.jfoodeng.2013.09.029.

Pasaraeng E, Abidjulu J, Runtuwene MRJ. 2013. Pemanfaatan rimpang kunyit (Curcuma domestica Val) dalam upaya mempertahankan mutu ikan layang (Decapterus sp). J MIPA Unsrat 2: 84-87.

Putri GR. 2016. Penambahan kunyit terhadap masa simpan nugget jagung. J IImiah Teknol Industri (SAINTI) 13: 1-9.

Rahmawati N, Sudjarwo E, Widodo E. 2014. uji aktivitas antibakteri ekstrak herbal terhadap bakteri Escherichia coli. J IImu-IImu Peternakan Universitas Brawijaya 24: 24-31.

Rita WS. 2010. Isolasi, identifikasi, dan uji aktivitas antibakteri senyawa golongan triterpenoid pada rimpang temu putih (Curcuma zedoaria (Berg.) Roscoe). J Kimia 4: 20-26.

Shon J, Choi YH. 2011. Effect of edible coatings containing soy protein isolate (SPI) on the browning and moisture content of cut fruit and vegetables. J Appl Biol Chem 54: 190-196. DOI: 10.3839/jabc.2011.032.

Silva MAD, Bierhalz ACK, Kieckbusch TG. 2015. Alginate and pectin composite films crosslinked with $\mathrm{Ca}^{2+}$ ions: effect of the plasticizer concentration. Carbohyd Polym 77: 736-742. DOI: 10. 1016/j.carbpol.2009.02.014

Singh P, Nanda A. 2013. Antimicrobial and antifungal potential of zinc oxide nanoparticles in comparison to conventional zinc oxide particles. J Chem Pharm Res 5: 457-463.

Torabi Z, Nafchi AM. 2013. The effects of $\mathrm{SiO}_{2}$ nanoparticles on mechanical and physiccochemical properties of potato starch films. J Chem Health Risk 3: 33-42.

Utami R, Nurhartadi E, Putra AYT. 2013. Pengaruh penambahan minyak atsiri kunyit putih (Kaempferia rotunda) pada edible film pati tapioka terhadap aktivitas antimikroba dan sensoris. J Teknosains Pangan 2: 51-56. 
Wan VCH, Kim MS, Lee SY. 2005. Water vapor permeability and mechanical properties of soy protein isolat edibel films composed of different plasticizer combinations. J Food Sci 70: 387391. DOI: 10.1111/j.1365-2621.2005.tb11443.x.

Wardana AA. 2016. Pembuatan Pelapis Bionanokomposit dari Tapioka, Nanopartikel $\mathrm{ZnO}$ dan Asam Stearat serta Aplikasinya pada Mangga Terolah Minimal. [Tesis]. Bogor: Fakultas Teknologi Pertanian, Institut Pertanian Bogor.
Yousef JM, Danial EN. 2012. In vitro antibacterial activity and minimum inhibitory concentration of zinc oxide and nano-particle zinc oxide against pathogenic strains. J Health Sci 2: 38-42. DOI: 10.5923/j.health.20120204.04.

Yu J, Yang J, Liu B, Ma X. 2009. Preparation and characterization of glyserol pasticized-pea starch/ZnO-carboxymethyl cellulose sodium nano-composites. Biosource Technol 100: 28322841. DOI: 10.1016/j.biortech.2008.12.045. 